\title{
Nutritional studies on East African herbivores
}

\section{Digestibilities of dry matter, crude fibre and crude protein in antelope, cattle and sheep}

\author{
BY PAMELA ARMAN* \\ Makerere University, Kampala, Uganda \\ AND D. HOPCRAFT \\ PO Box 44092, Nairobi, Kenya \\ (Received 26 fuly 1974 - Accepted I October 1974)
}

\begin{abstract}
I. A series of digestibility trials was done using four animals of each of the following species: Friesian cattle (Bos taurus), Boran zebu cattle (Bos indicus), Corriedale sheep, fattailed sheep, eland (Taurotragus oryx Pallas), Coke's hartebeest (Alcelaphus buselaphus cokei Günther), Thomson's gazelle (Gazella thomsonii Günther) and bush duiker (Sylvicapra grimmia L.).

2. Two batches of pelleted food were prepared from ground maize cobs, cassava, wheat bran, maize bran and decorticated cottonseed cake. For each batch, five diets (A-E) were prepared containing 65 (A)-r35 (E) g crude protein (nitrogen $\times 6.25) / \mathrm{kg}$ dry matter. The crude-fibre contents of all the diets were similar $(120-138 \mathrm{~g} / \mathrm{kg}$ dry matter).

3. The animals were given the high-protein diet $(E)$, then given diets with decreasing protein contents finishing with the low-protein $\operatorname{diet}(\mathrm{A})$. The antelope and half the sheep were given diets from the first batch of pelleted food, the other four sheep and all the cattle were given diets from the second batch of food.

4. In sheep, there were significant differences in digestibility between the two batches of food.

5. There were no significant differences in the over-all mean digestibilities of all diets when given to cattle (both species) and sheep. However, with diet E, dry-matter digestibility was higher in sheep than in cattle $(P<0.05)$ : the reverse was true with $\operatorname{diet} \mathrm{A}(P<0.001)$. Crude-fibre and crude-protein digestibilities followed a similar pattern. The differences between Corriedale and fat-tailed sheep were not significant. The only significant difference between the two species of cattle was the higher digestibility of crude protein in Borans given diet $\mathrm{E}(P<0.05)$.

6. The over-all mean digestibility of the dry matter was higher $(P<0.001)$ in hartebeest and duiker than in sheep; in Thomson's gazelle $(P<0.01)$ and eland $(P<0.001)$ it was lower than in sheep. The values for crude-fibre digestibilities varied in a similar way.

7. The mean apparent digestibility of crude protein was higher $(P<0.001)$ in eland, hartebeest and duiker than in sheep and gazelle.

8. The results are discussed in relation to the feeding habits and digestive physiology of the various species.
\end{abstract}

Investigations using wild animals are of great interest. Wild herbivores in Africa attract the attention of the nutritionist because they usually appear to be in good condition, and suffer less severely than domestic animals in droughts. This may result from selective feeding and their freedom to migrate in search of food and water: domesticated livestock are usually enclosed at night and have a shorter grazing time. There may also be physiological differences between species which make wild herbivores particularly well adapted to their environments. To fully understand ruminant

* Present address: Airypark Cottage, Contlaw Road, Milltimber, Aberdeen ABI oER. 
physiology, as well as to gain an insight into the changes produced under domestication, we ought to study wild species in comparison with domesticated ones.

The aim of the experiments reported here was to obtain further information about the variation in digestive efficiency and physiology of ruminants. During I968-9 a series of digestibility trials was done using sheep, cattle and four species of antelope, which were given diets of progressively decreasing protein contents. This was intended to gradually deplete protein reserves and simulate the natural transition from wetseason to dry-season conditions. This experimental design had the disadvantage that comparisons were made between different diets fed consecutively to the same animals and, therefore, at increasing age and weight of the animals, but these factors may not have greatly affected the digestibility results reported here. If there was interaction between succeeding treatments, the alternative, a randomized design, would also have been open to criticism.

\section{EXPERIMENTAL}

\section{Animals and diets}

Animals used in Kampala, Uganda. Four young castrated male Corriedale sheep weighing about $35 \mathrm{~kg}$ were bought in Kenya. Their fleeces were kept fairly short. When these sheep were given the pelleted diets they occasionally produced rather wet faeces; their pre-feeding periods were extended until the faeces returned to normal. One had to be removed from the experiment towards the end when its food intake fell to a very low level. Four fat-tailed sheep, two male and two female, weighing $16-24 \mathrm{~kg}$, were bought in Uganda. They were of unknown age but all were still growing, and adapted to the experimental diets well.

Four bush duiker (Sylvicapra grimmia L.) were obtained locally. One was a mature male and the other three (one male and two females) were immature. All had been hand-reared and were unafraid, although the adult male was rather aggressive. Their initial weights ranged from 7 to $\mathrm{I} \mathrm{kg}$. They were ideal for experimental work, being small and placid, and even wild adults could be tamed in captivity. They readily ate the pelleted diets. In the wild they are browsers (Wilson \& Clarke, I962) with a highly nutritious diet.

Animals used at Athi River, near Nairobi, Kenya. The four eland (Taurotragus oryx Pallas) were all tame, and rather easier to handle than some of the cattle: all had been hand-reared or caught when young. There were two of each sex. Their initial weights ranged from 130 to $300 \mathrm{~kg}$ and none was fully grown. Eland are selective feeders whose normal diet consists of grass and much browse and herbs (Stewart \& Stewart, 1970). They readily ate the pelleted diets.

The four young Friesian (Bos taurus) steers used, of initial weights $150-270 \mathrm{~kg}$, were selected to match the eland in body-weight, and were younger than the elands and Boran zebus (Bos indicus). They adapted well to the experimental diets. The initial weights of the four Boran zebu steers were similar. Two of them started to lose their appetites in the middle of the trials, but their food intakes improved again after all had had a short period on pasture between periods of feeding on diets $\mathbf{C}$ and $\mathbf{B}$.

Four immature Coke's hartebeest (Alcelaphus buselaphus cokei Günther), three male 
Table I. Ingredients $(\mathrm{g} / \mathrm{kg}$ ) and chemical composition ( $\mathrm{g} / \mathrm{kg}$ dry matter) of two batches of diets given to different species of East African herbivores

\begin{tabular}{|c|c|c|c|c|c|c|c|c|c|c|}
\hline & & & & & & & & & & \\
\hline & & & & & & & & & & $\varepsilon$ \\
\hline Cassava flour & & & & & & & & & & \\
\hline Ground maize cobs & & & & & & & & & & \\
\hline Maize bran & & & & & & & & & & 88 \\
\hline Wheat bran & & & & & & & & & & 34 \\
\hline Decorticated cottonseed cake & & & & & & & & & & 8 \\
\hline Molasses & & & & & & & & & & ;o \\
\hline Supplements and salt & & & & & & & & & & 30 \\
\hline & & & & & & & & & & \\
\hline Batch ... & $\mathrm{r}$ & 2 & $\mathrm{r}$ & 2 & I & 2 & I & 2 & I & 2 \\
\hline Crude protein* & 65 & 64 & 72 & 82 & 87 & 104 & \pm 16 & 120 & 137 & I35 \\
\hline Petroleum spirit extract & 27 & 26 & 39 & 45 & 46 & 49 & 62 & 66 & 63 & 65 \\
\hline Crude fibre & 122 & 120 & I34 & 130 & r 34 & 137 & I34 & ${ }_{13} 8$ & 134 & I 34 \\
\hline Ash & 62 & 48 & $6 I$ & 46 & 65 & 58 & 68 & 64 & 74 & 55 \\
\hline Nitrogen-free extract & 724 & 742 & 694 & 697 & 668 & 652 & 620 & 612 & 592 & $6 \mathrm{II}$ \\
\hline Organic matter & $93^{8}$ & 952 & 939 & 954 & 935 & 942 & 932 & 936 & 926 & 945 \\
\hline
\end{tabular}

and one female, weighing $69-79 \mathrm{~kg}$ were used. All had been bottle-fed but they remained easily frightened and difficult to handle. They adapted slowly to the experimental diets and to enclosure in a metabolism cage, and one was withdrawn after the diet $\mathrm{C}$ feeding period, after injuring a leg. The normal diet of this species is grass (Casebeer \& Koss, 1970), often with a high fibre content, and they were probably not well adapted to pelleted, medium-fibre diets. These animals seemed to be under more stress than the other species.

Three of the four Thomson's gazelles (Gazella thomsonii Günther) were young hand-reared males: the fourth was a nearly adult male, caught wild, which was tamed by being first confined in a darkened building and then being gradually accustomed to handling. Their initial weights were $9-2 \mathrm{I} \mathrm{kg}$ and all adapted well to the experimental conditions. Their faeces were occasionally rather wet, and experimental periods were prolonged where necessary. These gazelles are mixed feeders which eat grass and dicotyledons (Stewart \& Stewart, 1970).

At the start of the trials, two of the hartebeest became ill and died. Salmonella typhimurium was isolated from the first to die. The metabolic effects of disease in these animals have been reported (Arman \& Hopcraft, 1971). After disinfection, the trials were resumed a month later in a different building with replacement animals, and there was no further disease outbreak.

Housing and climatic conditions were not the same at the two locations, but the animals were acclimatized and were slowly adapted to the experimental conditions and showed no sign of heat or cold stress. We have therefore analysed the results from the two sites together. 
Diets. There was no natural diet which would be acceptable to this range of species. Two batches of experimental diets were prepared from readily obtainable and uniform components. The five diets (A-E) in each batch differed in protein content although fibre contents were similar (Table $\mathrm{r}$ ). The diets were made up into $8 \mathrm{~mm}$ pellets. The animals started with the diet containing the highest amount of protein (E) and progressed through the range to the lowest (A).

\section{Experimental procedure}

The diets were allocated as follows: batch I was given to two Corriedale sheep, two fat-tailed sheep and all the antelope, and batch 2 was given to two Corriedale sheep, two fat-tailed sheep and all the cattle. The animals were cage-trained, using four different sizes of cage for the different species, before the feeding trials began, and were treated for intestinal parasites with thiobendazole. They were given diet $\mathrm{E}$ together with pasture or hay and when the pelleted diet was being freely eaten, the animals were individually penned and offered diet $\mathrm{E}$ to appetite. All were given drinking-water ad lib. Diets were replaced daily and intakes were recorded. When the food intake was reasonably constant (after at least 3 weeks) the amount of food offered was reduced to just above ( $\mathrm{I} \cdot \mathrm{O}_{3}-\mathrm{I} \cdot \mathrm{I}$ times) the mean daily intake, for the initial experimental period of ro $d$ or more.

After this period the animals were weighed and put in metabolism cages for separate faeces and urine collection for a further 8-12 d. Faeces were collected for a $24 \mathrm{~h}$ period. The urine was filtered into plastic bottles containing $50-250 \mathrm{ml} 6 \mathrm{M}$ sulphuric acid, depending on the urine volume (Martin, r966). As there were no cold storage facilities at Athi River, the amount of faeces and urine was measured daily. The urinary nitrogen loss was estimated by the Kjeldahl method; $5^{-10} \mathrm{ml}$ urine was digested and a portion was distilled into boric acid and titrated against $0.02 \mathrm{M}$-hydrochloric acid with a methyl red-bromocresol green indicator. The faeces were weighed and mixed and a $200 \mathrm{~g}$ subsample was dried at $105^{\circ}$ to constant weight and the daily dry-matter output was recorded. Crude-fibre and crude-protein contents were determined by the methods of the Association of Official Agricultural Chemists (1965). The mean $\mathrm{N}$ content of $5 \mathrm{~g}$ samples of fresh faeces collected daily for the 8-I2 $\mathrm{d}$ period for each animal on each diet was taken as the faecal $\mathrm{N}$ content. This procedure avoided errors resulting from losses by evaporation or urinary contamination of the bulked sample. For comparison, the $\mathrm{N}$ content of the dried bulked faeces was corrected for $\mathrm{N}$ losses on drying (Juko, Bredon \& Marshall, 196r). Any large discrepancy indicated urinary contamination of the faeces (this happened occasionally with the small antelope, whose faeces were sometimes voided in clumps) and the difference was added to the urinary $\mathrm{N}$ loss. Samples of the food were also taken daily and proximate analysis was done using the methods of the Association of Official Agricultural Chemists (1965).

At the end of the collection period for diet $E$ the animals were removed from their cages, individually penned and offered diet $\mathrm{D}$, the amount offered being increased until intake was again reasonably constant $(7-9 \mathrm{~d})$. The trials were repeated, using the same procedure, for diets $\mathrm{C}, \mathrm{B}$ and $\mathrm{A}$. 
Table 2. Dry-matter digestibility of the two batches of five diets containing different amounts of protein (high low, $E$ - $A$ respectively) given to different species of East African herbivores

(Mean values for four animals of each species)

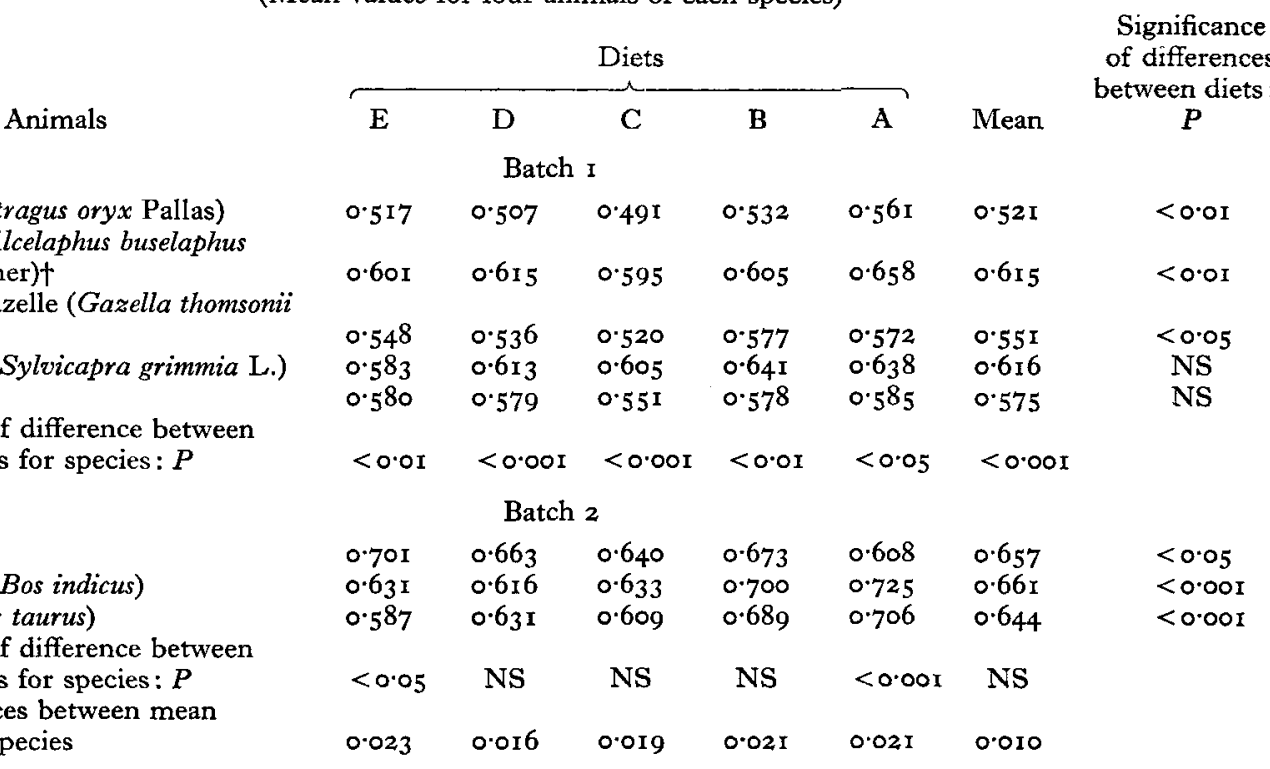

Interaction between species and diets was significant: $P<0.01$.

NS, not significant.

* Two fat-tailed and two Corriedale sheep.

$\uparrow$ Missing values inserted for one animal on two diets.

Water intakes were recorded in some of the trials. With diet A, a final $3 \mathrm{~d}$ period of restricted intake (half the normal consumption) was imposed on some of the animals.

\section{RESULTS}

Food intakes will be discussed more fully in a later paper. The dry-matter intakes of the five diets were ( $\mathrm{g} / \mathrm{kg}$ body-weight per $\mathrm{d}$ ): Friesian cattle $24-27$, Boran zebus 20-23, Corriedale sheep 28-37, fat-tailed sheep 32-44, eland $26-34$, hartebeest 23-28, gazelle $37-47$ and duiker $35-40$.

Comparison between batches $\mathrm{I}$ and 2 of the diets. The apparent digestibilities of the diets are shown in Tables 2,3 and 4 . The digestibility of dry-matter of the diets from batch I differed significantly from that of diets from batch 2 when both were given to sheep $(P<0.001)$ (Table 2$)$; the value for batch 2 diets was consistently higher. The change in digestibility with protein content was greater for diets from batch 2.

'Between breeds and species' differences in digestibility. Because of the large batch differences, inter-species comparisons could only be made between animals given diets from the same batch, but sheep could be used as a common basis for comparison.

The differences in digestibility between the two breeds of sheep were nonsignificant, but the two breeds were kept separate in the 'between animals' analysis. 
Table 3. Crude-fibre digestibility of two batches of five diets containing different amounts of protein (high-low, $E-A$ respectively) given to different species of East African herbivores

(Mean values for four animals of each species)

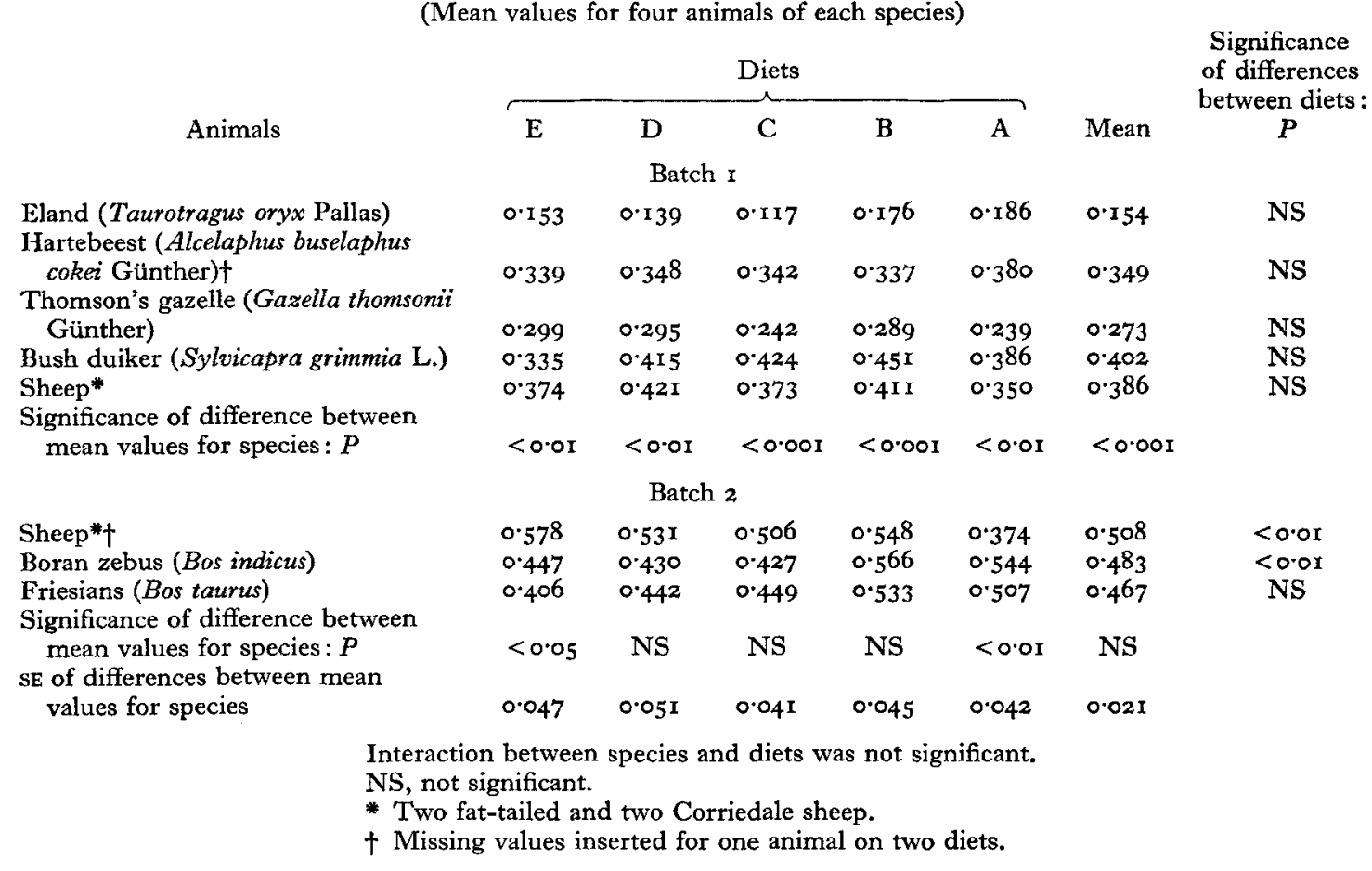

Within batch 2, the mean digestibilities for the two species of cattle were not significantly different from those for sheep. The over-all means did, however, mask differences between the diets. There were differences between cattle and sheep for diets $\mathrm{E}$ and $\mathrm{A}$. The dry-matter and crude-protein digestibilities of diet $\mathrm{E}$ were lower $(P<0.05)$ for cattle than sheep and those of diet A were higher $(P<0.001)$. The variation in the digestibility of diets with different protein contents were therefore different for these species.

Individual animal differences within a species were significant only for Boran zebus $(P<0.00 \mathrm{r})$.

There were significant species differences between antelope and sheep. Protein digestibility was higher for eland than for sheep $(P<0.001)$ and dry-matter and crude-fibre digestibilities were lower $(P<0.00 \mathrm{r})$. Taylor \& Lyman (1967) also found that the digestibility of dry matter for eland was low $(0.52$ compared with 0.58 for cattle). The digestibilities of dry matter $(P<0.01)$ and crude fibre $(P<0.001)$ were lower for Thomson's gazelle than for sheep, but there were no differences in protein digestibility. Dry-matter, crude-fibre and crude-protein digestibilities were higher for hartebeest and duiker than for sheep $(P<0 \cdot 001)$.

'Between diets' differences in digestibility. Within the same batch, differences were significant in many instances, although the variation did not always follow the 
Table 4. Apparent digestibility of crude protein (nitrogen $\times 6.25)$ of two batches of five diets containing different amounts of protein (high-low, $E-A$ respectively) given to different species of East African herbivores

(Mean values for four animals of each species)

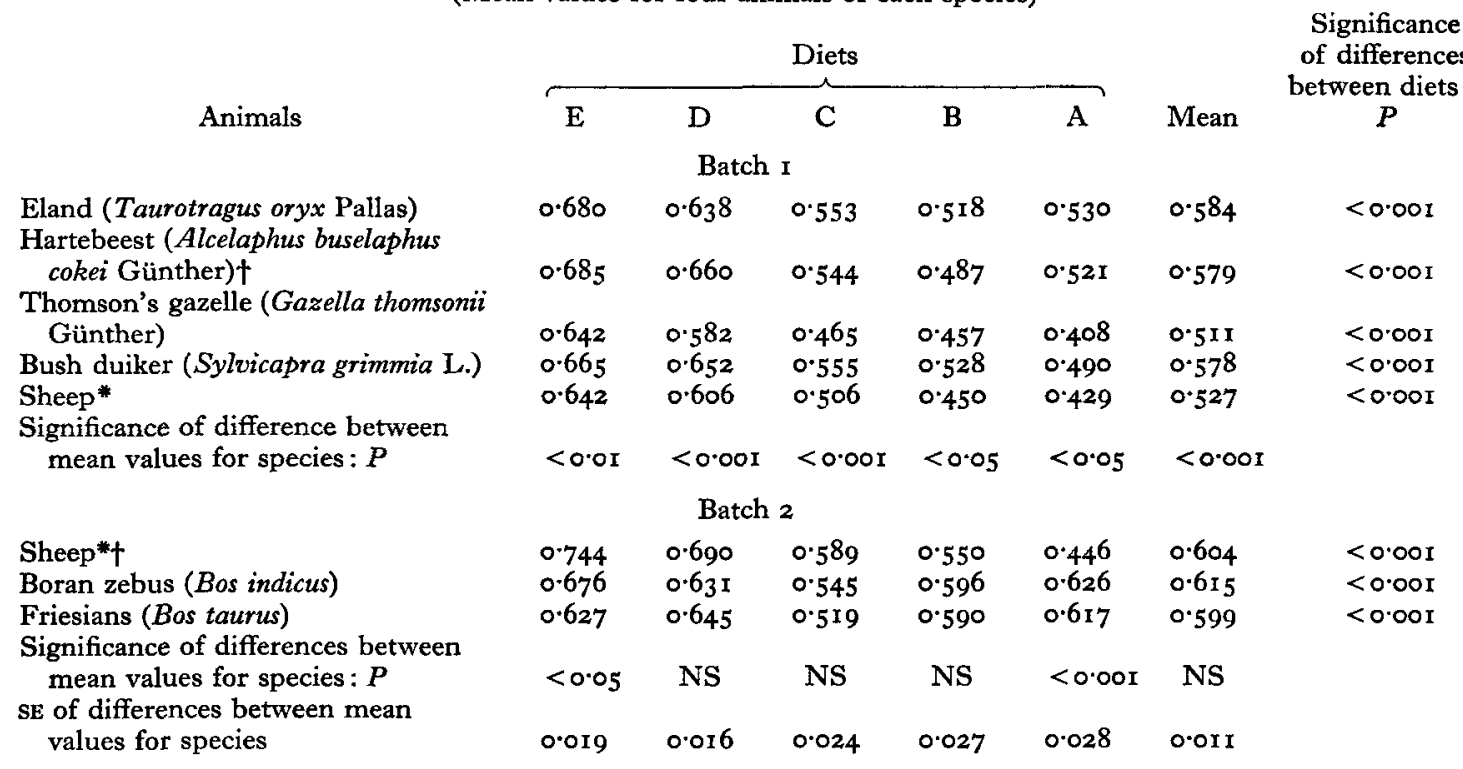

Interaction between species and diets was significant: $P<0.00 \mathrm{r}$.

NS, not significant.

* Two fat-tailed and two Corriedale sheep.

$\uparrow$ Missing values inserted for one animal on two diets.

expected pattern of a decrease in digestibility with decreasing protein content. Crudeprotein digestibilities did decrease from diet $\mathrm{E}$ to $\operatorname{diet} \mathrm{A}$, except when these diets were fed to cattle. In some instances there was a tendency for digestibility to be similar in diets $\mathrm{E}$ to $\mathrm{C}$ and then to increase with the low-protein diets (B and $\mathrm{A}$ ), which may have been richer in starch.

\section{DISCUSSION}

Digestive efficiency in the domesticated species. We have shown no significant over-all differences between sheep and cattle, although the digestibility of the high-protein diet was higher for sheep and that of the low-protein diet was higher for cattle. Apart from the isolated instance of the digestibility of crude protein of diet $\mathrm{E}$ (higher for the zebus), there were no differences between the two species of cattle. French (1940) and Phillips, Hungate, McGregor \& Hungate (1960) also found no differences between the two species of cattle, although Phillips (196I) reported that the digestibility of poor-quality hay was slightly higher in zebus. Ashton (r962), in Australia, found that the digestibility of pasture was higher for Brahman zebus than for Herefords, although Howes \& Hentges ( 1964 ) found that digestibility for Herefords was more affected by protein intakes than that for Brahmans and suggested that the latter are better 
adapted to low-protein forages. Karue, Evans \& Tillman (1972) reported no differences in dry-matter digestibility between Herefords and Borans, although protein digestibility was higher for the latter: we have shown a similar difference with diet $\mathrm{E}$. Rogerson, Ledger \& Freeman (1968) discussed the differences between the two species of cattle and reported similar values for digestibility and efficiency of utilization of energy. Boran zebus do, however, have a lower fasting metabolism, a lower food intake and grow more slowly than Herefords (Rogerson, 1970). We have found similar appetite differences between Borans and Friesians.

The diets fell within the range where $\mathrm{N}$ content has only a small effect on drymatter digestibility (Glover \& Dougall, 1957; French, Glover \& Duthie, I960): $\operatorname{diet} A$ contained more than $\operatorname{log~N} / \mathrm{kg}$ dry matter, the level at which rumen fermentation becomes seriously limited. In most instances, crude-protein digestibility decreased from $\operatorname{diet} \mathrm{E}$ to $\operatorname{diet} \mathrm{A}$.

Digestive efficiency in the wild species. The differences between the two batches of diets made a direct comparison between antelope and cattle impossible, but the antelope could be compared with sheep. Over-all mean digestibilities of dry matter were of the order: hartebeest and duiker $>$ sheep $>$ Thomson's gazelle $>$ eland $(P<0.001,0.01$ and 0.001 respectively). Crude-fibre digestibilities were of a similar order: duiker, hartebeest and sheep $>$ Thomson's gazelle $>$ eland $(P<0.00 \mathrm{r}$ and 0.00 I respectively). For mean crude-protein digestibility, the order was different: eland, duiker and hartebeest $>$ sheep and gazelle $(P<0.001)$. Sheep were thus intermediate between the four antelope species in their ability to digest these pelleted, medium-fibre diets.

The relative digestive efficiencies of the species fed the pelleted diets might not be the same as those of animals given more natural diets, and it would be valuable if more comparative work could be done on normal foods, although it is difficult to find natural diets which a wide range of species will eat. It is possible also that some of the animals were affected by confinement (Mautz, 1971).

It is interesting to consider the results in relation to the normal feeding habits of these animals. East African ruminants can be divided into three types (Hofmann, r968; Hofmann \& Stewart, 1972): (a) selective feeders (including browsers) having a diet of high nutritive value, low fibre and high protein contents; these animals have relatively small rumens and include duiker and eland (which may eat considerable amounts of grass in the wet season); (b) mixed feeders, taking grass plus some dicotyledonous herbage, e.g. sheep and Thomson's gazelle, and (c) roughage eaters (grazers) whose diet is largely grass, which is often of high fibre and low protein content, especially in the dry seasons; these have large rumens and include hartebeest, wildebeest and cattle. Feeding habits follow the taxonomic relationships in many instances, but do not seem to be closely related to size. Even the small oribi (Ourebia ourebia) weighing $\mathrm{r} 3-\mathrm{r} 6 \mathrm{~kg}$, is able to subsist on a grass diet.

With selective feeders the food would be fermented very rapidly and the rumen epithelium is densely papillated, a characteristic which would facilitate absorption. Such species would be less dependent on rumen fermentation than roughage eaters either for cellulose breakdown or for protein synthesis. The food may be retained in 
the relatively small rumen for a short time only. However, no comparative work on rates of passage has been reported. Hungate, Phillips, McGregor, Hungate \& Buechner (1959) reported some studies of fermentation rates in various species and found them to be highest in small antelope. However, to establish that species differences in retention time or fermentation rates result from physiological rather than dietary variations, it will be necessary to carry out studies using a diet of constant composition and at a relatively constant level of intake, and the species studied should include a wide range of both selective feeders and grazers.

If the eland given our experimental diets did retain food in the rumen for a shorter time than the cattle, the amount of bacterial protein formed in the rumen might have been lower in the eland, and this could account for the low $\mathrm{N}$ content of the faeces and the high apparent digestibility of the crude protein, and for the low crude-fibre digestibility. Species with a short rumen retention time might be worth domesticating because they may be well suited to high-cereal diets. The normal diet of selective feeders would have a low fibre content and inefficiency in its utilization could be compensated by a large appetite, as in the eland. The duiker is also a selective feeder and showed not only a high protein digestibility but also a remarkable ability to digest carbohydrate. Although they digest dietary protein very efficiently, selective feeders might utilize absorbed $\mathrm{N}$ less efficiently and recycle urea to a lesser extent than the grazers. This point has already been discussed for eland by Taylor \& Lyman $(1967)$.

Grazers have large rumens which probably retain food for long periods. They should digest cellulose very well and achieve high $\mathrm{N}$ retentions on low-protein diets, as a result of the formation of bacterial protein from recycled urea. The digestibility of all the pelleted diets was high for the hartebeest, and that of the low-protein diets $B$ and $A$ was relatively high in cattle. In the mixed-feeding group (sheep and Thomson's gazelle) dry-matter digestibilities were intermediate, although the protein digestibilities were unexpectedly low.

Digestive efficiency may not be equated with biological adaptation to the environment. A species which digests fibre inefficiently but has a large appetite (e.g. the eland) might be as successful as one which digests very well but has a smaller appetite (e.g. the hartebeest). A large appetite might be advantageous in obtaining more of limiting nutrients such as protein, minerals and carotene, and may explain how non-ruminant ungulates such as the zebra (Equus burchelli Gray and E. grevyi Oustalet) are able to subsist on poor-quality grass. A high metabolic rate and a high level of activity, necessitating a high food intake, may thus be an advantage where nutrients other than energy are limiting, and Taylor \& Lyman ( 1967$)$ have suggested that a large appetite with a high metabolic rate and a high critical temperature may help in maintaining water balance under dry conditions. The few studies which have been carried out on the metabolic rates of wild ruminants have tended to give high values (Rogerson, I968; Brockway \& Maloiy, I968).

The results indicated no relationship between digestive efficiency and body size. Assuming that retention time is shorter in smaller species, it would follow that the rate of digestion must be greater. More rapid rumen digestion in small species could 
result from improved maceration, differences in rumen flora, saliva or rumen fluid, or from a more rapid absorption of the end-products of digestion associated with a greater surface:volume ratio in the gut of small animals. The relationships between rumen function and body-weight are complicated by differences in feeding habits. There is considerable behavioural, anatomical and physiological adaptation among the ruminants and a number of species have evolved which can collectively utilize nearly all the vegetation in their various habitats.

The authors thank Unga Ltd, Nakuru, Kenya, for preparing the experimental diets. P.A. received a grant from the Makerere Research Grants Committee, and D.H. received funds from the National Science Foundation of America. They are very appreciative of the facilities provided by Mr and Mrs J. Hopcraft at Athi River, and P.A. would like to express her gratitude for their warm hospitality. They wish to thank Mr I. McDonald for statistical analyses, the East African Veterinary Research Organisation for lending metabolism cages, Mr J. Stanley for the loan of the Friesian steers, Dr C. R. Taylor for donating an eland, Mrs M. J. Delaney for giving two duiker, and King's College, Buddo, for giving one duiker. The following gave technical assistance: A. Binks, Miss V. Finch, P. Kavoo, J. Mukasa, W. Musila, H. Sorangi, J. Urimubenshi, M. Wambua, B. Wheeldon and J. S. Wood.

\section{REFERENCES}

Arman, P. \& Hopcraft, D. (I97I). Proc. Nutr. Soc. 30, 65 A.

Ashton, G. C. (I962). F. agric. Sci., Camb. 58, 333 .

Association of Official Agricultural Chemists (1965). Official Methods of Analysis roth ed. Washington, DC: Association of Official Agricultural Chemists.

Brockway, J. M. \& Maloiy, G. M. O. (1968). F. Physiol., Lond. 194, 22 P.

Casebeer, G. L. \& Koss, G. G. (1 970). E. Afr. wildl. F. 8, 25.

French, M. H. (I 940). F. agric. Sci., Camb. 30, 503 .

French, M. H., Glover, J. \& Duthie, D. W. (I960). F. agric. Sci., Camb. 48, 373.

Glover, J. \& Dougall, H. W. (1957). F. agric. Sci., Camb. 55, 39 r.

Hofmann, R. R. (1968). Symp. zool. Soc. Lond. 2r, I79.

Hofmann, R. R. \& Stewart, D. R. M. (1972). Mammalia 36, 226.

Howes, J. R. \& Hentges, J. F. (1964). Nature, Lond. 203, 784.

Hungate, R. E., Phillips, G. D., McGregor, A., Hungate, D. P. \& Buechner, H. K. (1959). Science, N.Y. I30, I I 92.

Juko, C. D., Bredon, R. M. \& Marshall, B. (Ig6r). F. agric. Sci., Camb. 56, 93.

Karue, C. N., Evans, J. L. \& Tillman, A. D. (1972). J. Anim. Sci. 35, 1025.

Martin, A. K. (1966). Br. F. Nutr. 20, 325.

Mautz, W. W. (1971). 7. Wildl. Mgmt 35, 366.

Phillips, G. D. (1.961). Res. vet. Sci. 2, 202.

Phillips, G. D., Hungate, R. E., McGregor, A. \& Hungate, D. P. (1960). F. agric. Sci., Camb. 54, 417.

Rogerson, A. (1968). Symp. zool. Soc. Lond. 21, 153.

Rogerson, A. (1970). E. Afr. agric. For. F. 36, 195.

Rogerson, A., Ledger, H. P. \& Freeman, G. H. (1968). Anim. Prod. 1o, 373.

Stewart, D. R. M. \& Stewart, J. (1970). Zool. Africana 5, I I 5.

Taylor, C. R. \& Lyman, C. P. (1967). Physiol. Zoöl. 40, 280.

Wilson, V. J. \& Clarke, J. E. (1962). Proc. zool. Soc. Lond. 138, 487. 